\title{
Accounting Standards for Awaqf: A Review
}

\author{
Zakir Hossen Shaikh $P h D$ \\ Lecturer in Commercial Studies Division \\ (Specialization-Islamic Banking and Finance) \\ Bahrain Training Institute, Ministry of Education \\ Kingdom of Bahrain \\ E-mail:zakir.shaikh@bti.moe.bh, skzakirI23@gmail.com \\ Adel M. Sarea $P h D$ \\ Associate Professor of Accounting \\ Department of Accounting and Economics \\ College of Business and Finance \\ Ahlia University, Manama, Kingdom of Bahrain \\ E-mail:adelsarea@yahoo.com, asarea@ahlia.edu.bh \\ Azam Abdelhakeem Khalid $P h D$ \\ Senior Lecturer in Accounting \\ Department of Accounting and Finance \\ Faculty of Management and Economics \\ Universiti Pendidikan Sultan Idris, Perak, Malaysia \\ E-mail:azamabdelhakeem@gmail.com
}

\begin{abstract}
The paper focuses on establishing accounting standards for the awqaf system in order to increase the efficiency and effectiveness of its operation. Standardization could cut costs and reduce the risk of mismanagement so that services provided by awqaf strengthen development fundamentals. Thus, it is essential that Muslim countries adopt unified accounting standards to ensure accountability and transparency of various transactions related to awqaf. This will provide flexibility concerning allocations of awqaf endowments so that priority will be given to projects related to people's basic needs. The proposed framework is designed based on the literature review to conceptualize the need of standardization of accounting for awqaf. The contribution of this paper is to add value to the literature of accounting for awqaf.
\end{abstract}

Keywords: Accounting Standards, Awqaf, Islamic Social Finance.

JEL Classification: M4I, E23.

\section{Introduction}

In the Islamic economy, the main objective of development is to meet people's basic needs by allocating resources in a productive manner so that to fulfill the Islamic fundamentals of equity, justice and freedom. The Islamic economy, driven by the shariah principles, offers equal opportunity to all members of the society to participate in market activities are to ensure that the entire society must benefit from the use of resources by imposing constraints on unethical practices as well as to reduce the risk of monopolistic power and market imperfections. From an Islamic perspective, economic development is to create a balance between spiritual and material consumption reflecting the desire for fulfilling the Islamic fundamentals and enhancing the society capabilities to promote welfare and sustain growth.

In Islam, resources are Allah's gift to man and therefore, the use of resources must be allocated in a manner to alleviate poverty and support development. The Islamic principles underscore the importance of production and distribution of income and wealth in a fair and just manner so that the entire community evolves and develops.

The institution of waqf in Islam is a voluntary contribution the aim of which is to finance variety of projects that enable the Muslim community alleviating poverty, improving the quality of life, increasing productivity and promoting knowledge and understanding. From development perspective, awqaf stimulates economic activities through voluntary expenditures which contribute to job creation and entrepreneurship. Awqaf is an Arabic term used in reference to Islamic 
religious endowments. Historically, the concept of waqf goes back to the time of Prophet aimed at creation of charitable endowments not only to helping those in need, but also to support the development of the community. Awqaf means donation of physical assets, including property, the purpose of which is to produce income for charitable requirements. However, experience from awaqf in Muslim societies show categories of awaqf endowments.

Awqaf is created through an act by individual donating part of his/her property to be used in compliance with the shariah for helping the poor.

The objective of this paper is to highlight the contribution of awqaf to socio-economic transformation in Muslim countries. The majority of these countries are suffering from low level of productivity and inadequate funding for development. Awqaf is a voluntary payment paid by people to support the poor and those in need. Most awqaf is allocated for such essential projects as education, health, social services, and public goods the benefit of which is to improve people's capabilities and increase their ability to contribute to society. For example, education and learning has always given priority among donors of awqaf so that people can gain knowledge and skills to participate in the economy. The poor and needy are to benefit from services provided by awqaf to create job opportunities and improve the quality of life. Experience with waqf has shown that voluntary funding can increase the ability of the country to support development through additional expenditures on development projects.

The development of awqaf institutions worldwide is due to the need and the demand from Muslims communities. However, awqaf institutions are growing globally as well as operating in different countries (Sarea, 2019). Previous studies about awqaf institutions have been conducted in different countries to address the awqaf in general. However, a few studies addressed the need of accounting standards of awqaf. Accounting reporting for waqf is differing from country to another. Thus, the need of accounting standards for awqaf could help for harmonization practice among Muslim countries. According to Md. Zain \& Abdul Rahman (2006) in Malaysia there are different approaches used by the councils in presenting their financial report. In related study conducted by Masruki \& Shafii (2013) It has been noted that different waqf institutions has its own accounting practice (Masruki \& Shafii 2013).

Awqaf accounting aspect is the issue of non-standardization in preparing the financial reports (Mohamed et al., 2006). It has been noticed that distinctive awqaf establishment has its own accounting practice. However, Hisham (2006) found that there was still no particular financial statement for awqaf.

In short, the motivation behind awqaf is to give repeating philanthropy that creates consistent income flow to the poor. The importance of waqf accounting and accountability of waqf establishments might be guaranteed. On the other hand, accounting system and benchmarks for waqf establishment dependent on "Accounting and Auditing Organizations for Islamic Financial Institutions (AAOIFI)” might be useful to improve its transparency and accountability.

\section{Importance of Awqaf Accounting Standards}

Reliability and responsibility of awqaf establishment can be improved by awqaf accounting. Ihsan et al. (2006) "boost the issues of reliability and responsibility in awqaf foundations is inadequate". In regards to this, there is an absence of responsibility and reliability in awqaf accounting (Masruki \& Shafii, 2013). There is also absence of the panel by the "Mutawalli" in managing awqaf. Furthermore, Marsoof (2004) noticed that development in accounting methodology is huge component of awqaf foundations. He proposed for deploying accounting methodology and norms for awqaf accounting.

Hosseini, Salari, \& Abadi (20I4) observed that "cash awqaf can be used as a waqf accounting instrument". In similar study, Siraj, (2013) cash awqaf can be a source of financing for investment and the status of financial reports decided the dimension of awqaf disclosure by "SIRC" in Malaysia is as yet missing. This is on the grounds that waqf financial statement summaries and is huge to disclose to clients in awqaf accounting. There is no systematic accounting framework rehearses in dealing with the assets of waqf (Hamdan, Ramli, Jalil, \& Haris, 2013),

As per Masruki \& Shafii (2013), "accounting is the most proper to shape truthfulness and accountability of waqf organizations”. For instance, improve regulatory, improvement in supervision, and improve accounting and reporting standards for waqf accounting by suggestion of the MASB.

With regard to the practices of financial reporting related to awqaf, A few activities have been done by ongoing investigations "(Nahar \& Yaacob, 20I I; Ihsan \& Shahul, 2007)" to see how the practices of financial reporting in organization managing awqaf and suggested various enhancements to these practices. Generally, these investigations have been drawn from waqf practices of Muslims residing in South-East Asia. "Most investigations reveal that, managing awqaf can be the best report to financial summaries as a charities (Sulaiman et al., 2009; Nahar \& Yaacob, 20I I; Ihsan \& Shahul, 2007)”.

Ihsan \& Shahul (2007) recommend that different earnings got from awqaf ought to be revealed in three classes: "endowment funds, restricted funds and unrestricted funds". The authors likewise suggest that waqf foundations pursue the Financial Activities utilized by any charities in the United Kingdom.

Ihsan (2007) found that the view of mutawalli in regard to duty and responsibility impact the method for awqaf foundations produce and spread accounting information. 
"Ihsan \& Mohamed Ibrahim (20II)" belief that awqaf institutions ought to be gradually honest in all financial activities such as "reveals its financial reports to public) states better responsibility. Different opinion, for example, the usage of competent work force find accounting information structure will indicate less critical of good responsibility”.

Another study conducted by Hosseini, Salari, \& Abadi (20I4) noticed that cash awqaf can use as an awqaf accounting instrument. In addition, cash awqaf has focal points to all parties, including the financial institutions, investor, and stakeholders. Hamdan, Ramli, Jalil, \& Haris (2013) "found that, there is no organized accounting framework in dealing with the fund of awqaf". This is on the grounds that the treasurers had limited knowledge in financial reporting.

"Yaacob, 2008; Masruki \& Shafii, 2013; Ihsan \& Adnan, 2009" have reasonably discussed about parts of responsibility in revealing of the managing awqaf trustees. "Masruki \& Shafii (2013) and Ihsan \& Adnan (2009)" feature that reports made by mutawalli ought to be set up to impose different stakeholders, such as waqif, non-governmental associations and beneficiaries. These reports must to give financial information as well as non-monetary information that reflects how these waqf have added to the social and financial welfare of their environment. Also, Yaacob (2008) features the requirement for more exposure on Sharia standards.

According to "Sulaiman et al. (2009)" the financial reporting activities of philanthropies are progressively suitable for organizations supervising awaqf. They consider organizations supervising awqaf must to disclose full financial information that empowers followers for register their managerial productivity shares. They found that the absence of categorization between different kinds of benefits and exchanges in the accounts prevents the calculation of this proportion in Malaysian colleges.

Lee (2004) indicates that giving financial reporting to government has turned out to be mandatory for nonprofit associations as a major aspect of their external accountability. This data will help waqf regulatory body in observing awqaf foundations. In Malaysia there has been an expanded open enthusiasm for awqaf establishments truthfulness, especially concerning their result, effect, viability and efficiencies. The public has kept on requesting the best standard and more significant truthfulness. In addition, recent cases on Islamic religious organizations in Malaysia were accounted for in the nearby media that give a central issue particularly on the responsibility of Islamic religious foundations including waqf establishment.

Additionally, there are charge and negative recognition with respect to the spending strategy, which ended up one of the components for the wiping out of commitments by 32,934 ordinary contributors to "Yayasan Pembangunan Ekonomi Islam Malaysia (YAPIEM), an Islamic association in Malaysia from February 2015 until February 20I6” (Teng, 2016). In addition, there are numerous Islamic non-profit associations that focuses on humanitarian aids including the person who are situated in Malaysia blamed for being engaged with fear based domination financing (Kamaruddin, 20I6; Othman \& Ameer, 20I4).

Besides, past examinations on awqaf revealing demonstrate that there was no particular rule in keeping up awqaf report, and there was no clarification of what sort of data ought to be given by a waqf foundation (Ihsan, 2007; Adnan $\&$ Ihsan, 2009; Nahar \& Yacoob, 20II). Besides, International Accounting Standards (IAS) and International Financial Reporting Standards (IFRS), and even Islamic reporting standard such as Financial Accounting Standard (FAS) issued by (AAOIFI) and local Islamic accounting standards such as Financial Reporting for Islamic Banking Institutions (FRIBI) issued by Bank Negara Malaysia (BNM) and Technical Release (TRi-3): issued by Malaysian Accounting Standard Board (MASB) are not completely suitable particularly for waqf detailing. Henceforth, "depending entirely on current accounting and reporting guidelines for waqf reporting is proven to be problematic as it leads to measure the performance based on financial numbers which are insufficient for waqf institutions" (Nahar \& Yacoob, 20I I).

Rationally, Ihsan \& Ayedh (2015) considered awqaf governance structure to promote awqaf manager's responsibility while supervising awqaf. They analyzed governance and accountability in waqf by: (i) reviewing the discussion on governance and accountability in awqaf institution; and (ii) examining the tawhid theoretical underpinnings relating to Islamic accountability and governance that builds up upon the concept of (one of God), amanah (accountability), adalah (fairness), and syura (collective/consultative decision-making). Their study on awqaf governance is exploratory and conceptual in nature, which is deficient of the discussion on awqaf governance and performance mechanisms.

For now, for awqaf performance reporting, Awqaf Institution ought to receive all recommended execution estimations by utilizing financial indicators as proposed by Arshad \& Zain (2017) \& Shafii et al. (20I4). There are I2 performance estimations by utilizing financial indicators proposed which are: "(i) program efficiency; (ii) cash availability; (iii) return of investment; (iv) fundraising efficiency; (v) operating income; (vi) objective achieved index; (vii) expected income achieved index; (viii) equity balances; (ix) revenue concentration; (x) administrative efficiency; (xi) operating margin; and (xii) income growth".

\section{Issues Due to Lack Standard}

Issues rose identified with awqaf accounting and reporting. First issue is no appropriate records and disclosure of awqaf resources, liabilities, revenues and costs in budget reports. In Muslim countries, numerous awqaf properties are not recorded appropriately or "some" have been disappeared (Ihsan \& Ibrahim, 20II). The waqf organizations likewise did not have allocation for depreciation of awqaf resources, method of depreciation and furthermore no different record for specific awqaf and general awqaf (Md. Zain \& Abdul Rahman,2006, Mohamed et al. 2006 \& Hisham, 2006). 
Ibrahim (200I), different awqaf councils utilize different accounting methods. Second issue is no updates for awqaf accounts (Abdul Rahman et al., I999). This is because of unsystematic documentation. Moreover, the errors in recording the financial transaction also are not being amended quickly (Abdul Rahman \& Goddard, 2003).

Siti Rokyah (2005) found that this low level of exposure was because of absence of qualified and trained accounting staff in taking care of the records and reports. Likewise, Md. Zain \& Abdul Rahman (2006) found the council neglected to submit yearly report for reviewing purposes. Be that as it may, however, there is no prerequisite in performance on financial report of awqaf, the awqaf organizations did not send the report for audit. (Ihsan \& Ibrahim, 20II).

Waqf foundations don't have accounting benchmarks to be followed in financial detailing (Siti Rokyah, 2005). This survey confirmed the examination done by Abdul Rahman et al. (I999) that there is absence of written strategies to record waqf financial transactions. The absence of accounting measures and written procedures to record waqf financial transactions will create the next issue in waqf accounting.

\section{The Need for Standardization of Waqf Accounting and Reporting}

Che Azmi, An., \& Hanifa, M. H. (20I5) investigate whether the financial statements of any awqaf institutions are Shariaconsistent. The study provides details regarding a contextual investigation of two Islamic-based originations that manage waqf. However, Che Azmi, An., \& Hanifa, M. H. (2015) found that both Islamic-based originations are utilizing different methods of accounting practices. Therefore, this examination additionally discovered that the current accounting practices established by associations which supervise awqaf need to include more exposure on their Sharia-compliance. In related study, Isa \& Harun, R. (20II) realized that awqaf properties are under supervision of each State religious' council. This will create a gap in awqaf administration and reporting. To conquer this issue, perhaps there is a need to set up a waqf administration net that is effective for all states in Malaysia. The technique "Benchmarking" must be executed by the state awqaf administration in different states all through the nation. Moreover, quality of awqaf administration can be improved and give more exposure by benchmarking previous studies, indicated the importance of standard for awqaf and provide the proposal for a good standard for awqaf. However, here is lack of study that examines intensely and comprehensively on the similarities and differences exist in the SIRCs with regard to the accounting and reporting for awqaf. Perhaps, it may be essential to initially explore the awqaf accounting practices in all SIRCs in Malaysia before developing a standard that may be used by all SIRCs to achieve the standardization.

According to Yunanda, R.A. (2016) to mobilize and distribute public funds, the establishment of awqaf will have important role in a country. The distinction of waqf is that awqaf assets should be presence in eternity, hence the assets must be managed well. Many public assets depend on transparency and accountability as the main factors. The purposes of transparency and accountability to prepare the financial reports, since there is no specific standards to accounting measurement and reports, however, this leads awqaf organization embrace the financial reporting practices to present their financial performance which are not entirely appropriate for non-profit. However, to ensure managing awqaf assets, the organizations must follow perpetual existence as a unique of Islamic principles of waqf. When financial reports ensuring the transparency and accountability it could be useful to assess awqaf perpetual existence.

Study done by Masruki, R., \& Shafi, Z. (2013) on the needs for developing accounting standards and statement of recommended practice for charity (SORP) based on AAOIFI framework, they suggest that, the resurgence of awqaf institutions creates the need to establish good accounting system for these institutions. This paper aims to provide recurring charity that generates continuous income flow to the needy. Absence of standards and guidelines on accounting for awqaf excite the interest to examine the relevance of awqaf accounting, therefore, this could be assured by transparency and accountability of awqaf institutions.

On the other hands, study done by Arshad, R., \& Zain, N., M. (2017) on financial and non-financial that can be adapted by awqaf institutions to evaluate their performance discharging their accountability. awqaf institutions has been an upsurge interest of Muslim nations around the world, as it has been regenerated for the past previous years. Awqaf institutions demonstrate their performance as whether they have effectively and efficiency managed to discharge their accountability. Many previous studies have been conducted to measure the performance in private and public organization; hence, on performance measurement of awqaf institutions are still limited. The performance measurement of awqaf institutions should also focus on realizing the missions. However, this conceptual paper can provide important prudence on how awqaf institutions, performance may be measured and provide a tool to benchmark on the best practices that can be achieved.

Examining "accounting and management practices in two Indonesian awqaf institutions", this study intended to seek prove on how mutawallis discharge their accountability and it's expected to contribute on the improvement of waqf administration, hence, this study is the first attempt to address accounting issues in awqaf institutions practically in Indonesia. Two awqaf institutions i.e. "ABC and XYZ waqf foundations", interview, document review and direct observations are the methods used to collect the data, therefore, the finding shows that $\mathrm{ABC}$ more efficient managed and greater accountability and transparency than XYZ, however, due to the presence of Islamic ally committed professional in the former, better accounting 
information system and more academically qualified personal in the latter (Ihsan, H., \& Hmeed Hj. Mohamed Ibrahim, S., 20I I).

Study done by Sarea \& Azam (2018) on the need of accounting for awqaf and endowment the paper reviewed the articles in accounting for awqaf by using Google scholar method, however, the main results showed for testing this term "Accounting for endowment" we found "27" articles and for "Accounting for awqaf" they found "24" articles in April 2018. The authors have read the abstract and included only papers published in English. Therefore, this study relevant to Sharia scholars in Islamic finance industry for strategizing and encouraging to introduce accounting for WAQF in education system.

\section{Conclusion}

The absence of governance, regulations and standards on accounting for awqaf generates the interest of few researchers and academic to propose the best practices of awqaf accounting therefore, accounting for awqaf is "a useful means to discharge mutawalli's (trustee) accountability in waqf administration and management” (Masruki \& Shafii 2013).

Besides, accounting and reporting for awqaf is very crucial to enhance the practices of awqaf institutions due to the reason that awqaf deals with the charitable assets which meant for public. Up to date, there is an absence of specific standard or guideline on accounting and reporting for awqaf. The absence of standards may create, lack of transparency, efficiency and comparability are due to different accounting and reporting for awqaf as highlighted by previous scholars (Abdul Rahim et. al. 1999; Sarea, 2013).

Many scholars highlight on the need for a more reform and uniformity of awqaf management and administration in Malaysia especially in the legal framework and financial aspects which include accounting and reporting practices. They have suggested that a standard law in relation to awqaf be enacted and be adopted by each state so that there was uniformity in the law with regard to power and authority for the development of awqaf property (Hisham 2006; 2012; Masruki \& Shafii, 2013).

\section{References}

Abdul Rahman, A. R., Bakar, M. D., \& Ismail, Y. (I999). Current practices and administration of waqf in Malaysia: A preliminary study. Awqaf Report: Malaysia.

Arshad, R., \& Zain, N. M. (2017). Performance measurement and accountability of waqf institutions in Malaysia. In SHS Web of Conferences (Vol. 36, p. 00005). EDP Sciences.

Che Azmi, A., \& Hanifa, M. H. (2015). The Sharia-compliance of financial reporting practices: a case study on waqf. Journal of Islamic Accounting and Business Research, 6(I), 55-72.

Hamdan, N., Mohd Ramli, A., Jalil, A. \& Haris, A. (2013). Accounting for waqf institutions: A review on the adaptation of fund accounting in developing the Shariah-Compliant financial reports for mosque. Presented at World Universities Islamic Philanthropy Conference 2013 (WIPCON 2013), "Transforming Islamic Philanthropy For Ummah Excellence”, Organised by IKAZ and UITM, 4 \& 5 December. Menara Bank Islam.

Hasan, R., Hassan, M. K., \& Rashid, M. (2018). Cash Waqf Investment and Poverty Alleviation: Case Of Tabung Masjids In Malaysia. Journal of Islamic Monetary Economics and Finance, 4(2), I-I4.

Hasan, Z., \& Abdullah, M. N. (2008). The Investment of Waqf Land As An Instrument of Muslims' Economic Development in Malaysia. Dubai International Conference on Endowments' Investment, 4-6 February, United Arab Emirates.

Hisham, Yaacob. (2006). Waqf accounting in Malaysian state Islamic religious institutions: The case of Federal territory SIRC, Unpublished masters dissertation, International Islamic University Malaysia, Kuala Lumpur.

Hoyle, J.B., Schaefer, T.F., \& Doupnik, T.S. (2009). Advanced Accounting. New York, NY: McGraw-Hill.

Ihsan, H., \& Hameed Hj. Mohamed Ibrahim, S. (20II). WAQF accounting and management in Indonesian WAQF institutions: The cases of two WAQF foundations. Humanomics, 27(4), 252-269.

Isa, Z. M., Ali, N., \& Harun, R. (20II). A comparative study of waqf management in Malaysia. In International Conference on Sociality and Economics Development (Vol. I0, pp. 56I-565).

Masruki, R., \& Shafii, Z. (2013). The development of waqf accounting in enhancing accountability. Middle-East Joumal of Scientific Research, I3(I3), I-6.

Zain , M., \& Rahman, A. (2006). Determination of financial reporting practices o waqf by Malaysian State Islamic Religious Councils. IIUM International Accounting Conference III, 26- 28 June . Kuala Lumpur.

Mohamad Suhaimi, F., Ab Rahman, A., \& Marican, S. (20I4). The role of share waqf in the socio-economic development of the Muslim community: The Malaysian experience. Humanomics, 30(3), 227-254.

Sarea, A. M. (2019). Establishment of The First WAQF Bank in Bahrain: Exploratory Study. The Journal of Developing Areas, 53(2), 22I-228.

Sarea, A. M., \& Ahmed, A. A. K. (2018). Accounting for Endowment: A Review of the Literature. Proceeding of the 5th International Conference on Management and Muamalah 2018 (ICoMM 2018). 
Sarea, A., \& Hanefah, M. (2013). The need of accounting standards for Islamic financial institutions: evidence from AAOIFI. Journal of Islamic Accounting and Business Research, 4(I), 64-76.

Thaker, M. A. M. T., \& Thaker, H. M. T. (2015). Exploring the contemporary issues of corporate share waqf model in Malaysia with the reference to the Waqaf An-Nur Corporation Berhad. Jurnal Pengurusan (UKM Journal of Management), 45.

Toraman, C., Tunçsiper, B., \& Yilmaz, S. (2007, August). Cash Awqaf in the Ottomans as philanthropic foundations and their accounting practices. In 5th Accounting History International Conference, Banff, Canada (pp. 9-II).

Yaacob, H., \& Nahar, H. S. (2017). Investigating Awqaf Management, Accounting and Investment Practices in Malaysia: The Case of a State Religious Institution. Global Journal Al-Thaqafah, 7(I), 59-70.

Yayla, H. E. (20II). Operating regimes of the government: Accounting and accountability changes in the Sultan Süleyman Waqf of the Ottoman Empire (The I826 Experience). Accounting History, I6 ( ), 5-34.

Yunanda, R. A. (2016). Accountability of Islamic based non-profit sector: the case of waqf organizations. Jurnal Ekonomi dan Bisnis Islam (Journal of Islamic Economics and Business), 2(2), I05-I24.

\section{Copyrights}

Copyright for this article is retained by the author(s), with first publication rights granted to the journal. This is an open-access article distributed under the terms and conditions of the Creative Commons Attribution license (http://creativecommons.org/licenses/by/4.0/). 